\title{
TEORÍA GENERAL \\ de las economías de mercado
}

\section{Oscar Mañán}

\begin{abstract}
¿Qué tal si deliramos por un ratito?
¿Qué tal si clavamos los ojos más allá de la infamia para adivinar otro mundo posible?
\end{abstract}

Eduardo Galeano

Sean capaces siempre de sentir, en lo más hondo, cualquier injusticia realizada contra cualquiera, en cualquier parte del mundo. Es la cualidad más linda del revolucionario.

Ernesto Che Guevara

En 2014 se publicó en México Teoría general de las economías de mercado (Universidad Nacional Autónoma de México), que en Chile se tituló Economías de mercado: estructura y dinámica (LOM Ediciones, Santiago), un libro fundamental que rescata de modo magistral el enfoque de la economía política para analizar la realidad de las economías contemporáneas: las economías de mercado. Permítaseme hacer una semblanza del autor (a riesgo de contrariar su voluntad), pero siempre los contextos aclaran los textos, los explican y allanan su entendimiento.

\section{El autor}

José Carlos Valenzuela Feijóo es un dilatado académico de origen chileno y de raigambre latinoamericanista, un claro ejemplo de lo que alguna 
vez Gramsci denominó «intelectual orgánico». Intelectual orgánico de los sectores populares, cuya existencia material fue concebida por la lucha de clases en Chile, primero en la resistencia contra aquella cúpula militar encaramada en los intereses del imperialismo y luego en la batalla desde el exilio para deslegitimarla y debilitarla, a fin de que el pueblo chileno se desprendiera de ella. Pero también renovó sus votos cuando los «cicutas de la historia», al frente de la restauración democrática, sepultaron los sueños libertarios que fueron esencia de las contiendas populares de antaño.

$\mathrm{El}$ autor se fragua en este proceso, continuo e incesante, en el que la clase obrera, los sectores campesinos, los pequeños burgueses nacionalistas, el conjunto de sectores populares se organizan y demandan herramientas de análisis teórico, económico y político con el propósito de articular un proyecto de clase (para sí, diría Marx); ese es el papel que Valenzuela ha desempeñado desde hace décadas. El neoliberalismo y las estrategias imperialistas posteriores a las dictaduras conosureñas, las reformas económicas de liberalización a ultranza del comercio y las finanzas tuvieron en este académico un crítico implacable. Sus textos no sólo ayudaron a esclarecer el paquete ideológico que acompañaba la colonización cultural del neoliberalismo sino que mostraron su necesidad histórica y los límites materiales que anunciaban una muerte súbita.

No obstante, su obra no permanece en la praxis teórica, puesto que la trasciende y se instala en la esfera de lo político e ideológico-cultural donde alienta una transformación radical del capitalismo. Valga el reconocimiento a su trabajo, hoy constituido en baluarte indispensable para el análisis de la realidad latinoamericana y un recurso todavía más relevante para quienes soñamos sin dejar de construir la transformación revolucionaria de la sociedad capitalista.

Los que lo conocemos disfrutamos de su aguda crítica a los procesos económicos y políticos contemporáneos y su característica esencial que 
lo engrandece como ser humano, aquella descrita por el Che: «es capaz de temblar de indignación cada vez que se comete una injusticia en el mundo». Con todas las letras, es más que nada un compañero.

\section{El libro}

El texto de Valenzuela decanta (en sus dos tomos respectivos) los aportes de una vida dedicada al análisis crítico del capitalismo y a una construcción teórico-metodológica original enmarcada en la mejor tradición de la economía política clásica. El autor entrelaza un conjunto de mediaciones imprescindibles, de manera paciente y didáctica, al mejor estilo ingenieril de Marx y guardando la simpleza que destila en el más complejo de los razonamientos histórico-filosóficos del materialismo dialéctico.

Los aportes del libro resaltan por ser una construcción que hace dialogar los textos clásicos de la economía política (los pioneros, que por cierto no comienzan con Smith ni Marx pero que revisten el esfuerzo humano por dar cuenta de su/la naturaleza) con los más lúcidos pensadores contemporáneos. Examina en principio la ley del valor, como la ley madre que expone el funcionamiento de las economías de mercado, explica sus presupuestos básicos y erige la lógica explicativa a partir de la conceptualización, la asociación entre las diferentes categorías teóricas con aspectos parciales para el entendimiento del fenómeno; de forma que vincula al todo y su movimiento incesante. Es una expresión digna de la mejor dialéctica hegeliano-marxista para esclarecer la acumulación de capital y con ella el entendimiento del movimiento de la sociedad.

El libro no aborda únicamente los planteamientos del herramental científico más interesante de la economía política contemporánea, además efectúa una exposición didáctica y proporciona mediaciones y 
supuestos que los investigadores pueden utilizar en su avance dentro del arduo proceso de conocer para transformar. Asimismo, es preciso rescatar que el trabajo contrasta esta exposición teórico-metodológica ordenada y empíricamente fundamentada con aquella de los principales analistas y divulgadores de la ciencia económica del poder, que sirve como doctrina para la dominación de nuestros países.

Se plantean y reconstruyen en el tomo I las categorías para un análisis científico y objetivo de las economías de mercado, cuestión que por sí sola evidencia la debilidad y la deformación de las ideologías disfrazadas de teorías que aún no dejan de ser hegemónicas en la tendencia económica mayoritaria. En la primera parte disecciona las relaciones de propiedad en dichas economías de mercado, su importancia y contenido, y analiza la distribución social del poder patrimonial, la apropiación y distribución del producto generado.

Dentro del tomo II se examina el funcionamiento de las economías de mercado y la adecuación indispensable de la teoría del valor a fin de describir el movimiento de las economías contemporáneas. Su trabajo es un rescate de la mejor versión de Marx, en el sentido de ciencia viva, lejos de las formas apologéticas tan comunes en las propuestas escolásticas.

Para finalizar, el autor revaloriza la necesidad de pensar una transición hacia el socialismo y las condiciones de esa planeación democrática para el trabajo que recordaba Lenin; esa nueva sociedad nacería de la actual (otra vez vuelve a Marx para afirmar su visión histórica y dialéctica del incesante movimiento). La gran socialización de las fuerzas productivas del capitalismo contemporáneo, combinada con la debilidad regulatoria en que opera la ley del valor, constituyen las condiciones materiales que conducen hacia el «progreso humano», el cual podría ser transformado por una revolución social en un proceso civilizatorio en el que ya no se beba el néctar «en el cráneo del sacrificado». 